\title{
KIRGIZ TÜRKLERINNDE ÖLÜM VE ÖLÜM ÖNCESİ İNANIŞLAR
}

\section{DEATH AND PRE-DEATH BELIEFS IN KYRGYZ TURKS}

Ali ÜNAL*

$\ddot{O} z$

Ölüm, insan hayatının en önemli gerçeklerinden biridir. Ölümün algılanışı insanın hayata bakış tarzına, inancına, yaşadığı hayatın şartlarına ve içinde bulunulan duruma göre değişiklik gösterdiği muhakkaktır. Kimi zaman acıklı kimi zaman kurtuluş olarak bakılan ölüm hadisesi çeşitli kavram ve düşünce etrafinda gelişir. Türk dilli ve Türk soylu halkların kültüründe ölüm olgusunun geniş bir yer tuttuğu gözlemlenir. İnsanın düşünce hayatında önemli bir konuma sahip olan Türk kültürünün mihenk taşlarından birini teşkil eden Kırgız toplumunda, ölüm olgusu ve bu bağlamda ortaya çıan inanış ve kavramların halkın zihninde nasıl algılandığ geleneksel Türk inançlarının gerekse İslami kaide ve uygulamaların her alanda olduğu gibi ölüme bakış açısında da derin tesiri olduğu Kırgız toplumunda ölüm, ölüm olayının toplumdaki yeri, ölüm belirtileri, vasiyet, helalleşme, şehadet getirme âdet ve inançları ile kavramları üzerinde durularak halkın ölüm olayına yaklaşımı ortaya konmaya çalışılmıştır..

\section{Anahtar Kelimeler}

Kırgız Türkleri, kültür, ölüm, ölümle ilgili ritüeller ve kavramlar, inanış.

\section{Abstract}

Death is one of the most significant facts of human life. The perception of death varies according to people's outlooks on life, beliefs, living conditions and their life situations they experience. Death is sorrow, but it sometimes is regarded as a salvation from torments. The history of death is developed around various concepts and ideas. In the Kyrgyz society, one of the milestones of the Turkic culture which has an important position in human's life is curiosity; how the phenomenon of death, beliefs and concepts emerged in this context and perceived in the minds of people. Death has an important role in the culture of the Turkic speaking and Turkic descent people. In this paper the role of death in the Kyrgyz society has been emphasized where the traditional Turkic beliefs are deeply influential in the view of death as well as the Islamic precepts and practices in every area, the statements of death, the will, the law of salvation.

\section{Keywords}

Bektashi, Bektashism, joke, the values of Bektashi, content analysis. 


\section{Giriş}

Her toplum, insanlık tarihi boyunca ölüm denen kaçınılmaz sonun üzerinde kafa yormuş ve kendince bu duruma bir hal çare aramaya çalışmış, bütün insanlığın üzerinde durduğu en önemli meselelerden biri olagelmiştir. Sadece günümüzdeki çağdaş, köklü ve büyük medeniyetlerde değil aynı zamanda konar göçer veya yerleşik hayata geçmiş küçük ölçekli kabile ve aşiretler, çok eski topluluklar insanla ilgili ölüm bilmecesini çözmeye çalışmış ve kavrayışları nispetinde ona çeşitli manalar yüklemeye gayret etmişlerdir. İnsanın benliğinde derin tesir bırakan ölüm olayı, toplumun genelinin gelenek, görenek, örf, âdet, destan, masal, hikâye ve inançlarında yer etmiş ve anlamlandırılmaya çalışılmıştır. Bu durum kavrayış ve anlayışlar çerçevesinde pek çok inanışın, bir o kadar da farklı uygulamaların meydana gelmesine neden olmuştur. Ayrıca bu inanışların her ulusa, her topluma, her bölgeye, her yöreye, hatta aynı yörede yaşayan her haneye varıncaya kadar farklılık gösterdiğinden söz edilebilir. Nihayetinde her çevrenin ölüme karşı bir bakış açısı olduğu gibi ölen kişiye duyulan muhabbet ve hürmetin zamanla uygulama anlamında da farklılığın oluşmasında önemli bir etken olacağı aşikârdır. Dolayısıyla insan hayatının sonu anlamına gelen ölüm olgusu birçok inanış ve ritüeli beraberinde getirdiği gibi insan ve toplumların belleğine derin tesir bırakmıştır.

Tabu ve örtmece sözlerin çıkış itibarıyla çok uzun tarihsel bir sürece dayalı olduğunu görürüz. İnsanoğlunun -tarih sahnesine çıktı̆̆ 1 andan itibaren- manevi kültürünün günümüze kadar gelenek- görenek, dini, batıl inançlara ve dil kültürüne dayalı olarak yaşadığ bilinmektedir. Örtmece sözler, bütün Türk lehçelerinde, halkın çeşitli inançlarına göre kutsal ya da kıymetli; korkunç veya tehlikeli sayılan varlıkların başat isimlerinin, hatta ona sesteş, benzer sözcüklerin yerine kullanılan dil göstergeleridir. Bundan dolayı, söylenmesi yasak sözcügün yerini örtmece sözler (euphemism) almaktadır. Eski zamanlarda ortaya atılıp günümüze kadar ulaşan tabu ve örtmece sözler, sebep sonuç bağlamında gelişen tarihi bir dil olgusudur. Bir kavramın gerçek isminin söylenmesini yasaklayan tabu sözler sebep, başat adın yerine geçen örtmece sözler ise sonuçtur.

İslâmiyet'e kadar ki inanç anlayışının esasını teşkil eden ata ervahına sığınma ve onlardan medet ummanın yaygın olduğu gerçeği dikkati çeker. Bu anlamda Türklerin ata ruhlarına muhtelif adlar verdiği anlaşılır. Arvak, arbak, tös olarak ifade edilen ata ruhlarının (Kalafat 1990: 58) Kırgız toplumunda arbak şeklinde ifade edildiği tespit edilir. Nitekim arbak olarak ifade edilen bu ruhların, "aç arbak" (aç ervah) ve "ak arbak" (ak ervah) olarak ikiye ayrıldığı görülür. Aç arbakın hayatta olanlara zarar ve ziyan verdiği; $a k$ arbakın ise hayatta olanlardan yardımını ve desteğini esirgemediği belirtilir (Attokurov 1997: 140). Bu anlamda ruhun ölümsüzlüğüne inanan, ata ervahını ulvi ve kutsal olarak addeden Kırgız toplumunda ata ruhunun mensup olduğu soyu her türlü kaza ve belalardan koruyacağına ve bütün kötülükleri defedeceğine inanilır (Murzakmatova 1997: 138).

Ölen atalara duyulan saygının bir başka tezahürü de insan yapısının tasavvurlarından ileri gelir. Eski Türkler insanı ten ve tın şeklinde algılar, insanın tenin tın olarak ifade edilen ata ruhunun sonsuza kadar yaşayacağına inanır. Ölen kimselerin çoğu zaman aile üyelerinin yardımına yeni şekliyle yetiştiği belirtilir. Kırgız toplumda günümüzde de yaygın olan "Manas Ata'nın arbagı koldosun" (Manas Ata'nın ruhu korusun) "Arbak koldosun" (Ervah korusun), "Arbagı menen koldop cürsün" (Ruhu ile korusun) gibi ifadeler eski inanç unsurlarının halk arasında var olageldiğinden haber vermektedir. Bekli de bu sebeple eski Türkler, mübarek olarak gördüğü kimseleri, hayatta olduğu gibi ölümden sonra da kızdırmamaya, onların 
öfkesini üzerlerine çekmemeye özen gösterirler. Bunları memnun edecek ve yardımlarını sağlayacak işler yapmaya çalışırlar (Kalafat 1990: 57). Bu anlamda atalar ervahına sığınmanın temelinde onların hâlâ yaşadığına dair mistik düşüncenin var olduğunu ileri sürmek mümkündür. Kişi ölse dahi ervahının hala yaşadığına, hayattaki soyunu gözlediğine ve onları koruyup kolladığına inanılır (Murzakmatova 1997: 143). Bu sebeple yaşayanlar, ölen atalarına itibar eder, saygı duyar ve onu memnun etmek için elinden gelen gayreti göstermekten çekinmezler (Cusupov 2001: 101).

Kırgız toplumunda insan ölümüne dair inanışlarda, animistik yani canın ölümsüzlüğü düşüncesinin büyük bir rol oynadığı görülür. Kırgız ananeleri, kişinin canının ölümsüzlüğü ve kişinin öbür dünyada da hayatını devam ettirdiğine kanaat getirir Bugün dahi halk arsında "Adamdın canı ölböyt al tigil düynödö da caşoosun ulanta beret." (Kişinin canı ölmez o diğer dünyada da hayatını devam ettirir) ifadesi eski anlayışın bir tezahürü olsa gerekir (Cumagulov 1995: 12). Bu düşünceyle Yunus Emre'nin dediği gibi Ölürse ten ölür, canlar ölesi değildir (Göçgün 1995: 40; Arpacık 2008: 134) tabiri Türk halkları arasında var olan ölüm ile ilgili ortak inanış ve anlayışı ortaya koyması bakımından önem arz eder.

"Arbak tirüü" (ervah canlı) inancı çerçevesinde ervaha ithafen her hafta perşembe günü akşamı cıt çıgaruu ${ }^{1}$ olarak bilinen koku çıkarma, Kur'an okuma âdeti yerine getirilir. Ayrıca eski dönemlerde canın tekrar tene döneceği inancıyla "söök" (kemik, naaş) yakıldıktan sonra ölen kişinin geri geldiğinde teni bulabilmesi için $t u l^{2}$ yaptı̆̆ı görülür. Sonraları ise naaşın defnedilmesi hadisesi husule geldiğinden dolayı tul yerine balbal dikilmeye başlandığı belirtilir. Buradan da anlaşılacağı üzere kimilerinin tabir ettiği gibi balballar bahadır veya hanların muhafızı veya fedaileri değil, doğrudan doğruya ölen veya öldürülen kişileri tasvir etmekte olan tul anlayış ve inanışının balbal şeklindeki tezahüründen ibarettir (Toktoşov 2005 7) şeklinde bazı kanılar mevcuttur. Farklı dönemlerde değişik özellikler gösteren tul inanışının son dönemlere kadar Kırgız toplumu arasında matem alametinin bir parçası olarak devam ettiği fakat günümüzde fazla rastlanan bir uygulama olmadığı da dikkat çekmektedir.

Kırgız toplumunun ölüm olayına ilişkin düşünceleri üzerinde geçmişin geleneksel tesirlerinden söz etmek mümkündür. Bu bağlamda tabiatla iç içe olan eski Kırgızların kışın suur olarak bilinen dağ sıçanının bükülerek yatıp öldüğünü, bahar geldiği zaman ise tekrardan dirildiğini gözlemlemişlerdir. Dolayısıyla kişi öldüğü zaman onu "ubaktıluu uyku" (geçici uyku)ya geçtiğine, Kün Kudayı olarak ifade edilen Güneş Tanrısı Iştör'ün oğlu Tamız'ın onu tekrar uyandıracağına inanırlar. Cesedi suur gibi kıvırarak defnetmeleri belki de eski gözlemlerin fikirsel anlamda olmasa da uygulama anlamında günümüzde hala geçerliliğini devam ettirdiği söylenebilir.

Tarihi süreç içinde gelişerek günümüzde hala varlığını zikredebildiğimiz Kırgız toplumundaki ölüm anlayışının, eski ve yeni birtakım inanç ve ritüelleri bünyesinde barındırdığı görülmektedir. Halkın fikirsel yaklaşımları önemli bir yer tutmaktadır. Bunun bariz örneklerine ise halkın söylemlerinde tespit etmek mümkündür. Halk arasında insanların fiziki açıdan bir mükemmelliğe sahip olduğu direnci ve dayanıklığı ile her şeyin üstesinden gelebilecek bir yapıda olduğu dile getirilir ve insanı sadece ecelin dize getirebileceği vurgulanır. Toplum nezdinde "Acal-ölüm cetpese, adam uulu cıgılbayt." (Ecel-ölüm ulaşmasa insanoğlu yıkılmaz.) düşüncesi bu olgunun doğruluğunu teyit eder mahiyettedir. Bununla birlikte "Acal cetip kün bütsö, kimdi sorboyt kara cer." (Ecel yetip gün bitse, kimi sorumaz-emmez kara

Ölen kişiyi anma ve hatırlama adına özellikle perşembe günleri yemek hazırlanması; yağda ekmeklerin pişirilerek koku çıkarılması âdeti.

2 Ölen kişinin el ile yapılma silueti; Bozüyün tündük kısmından veya evin sağ taraftaki giriş kapısına bağlanan kara bez veya kuyruk; ölen kişiyi tasvir eden ağaç veya yastıktan yapılan kukla; kocası ölen kadın, dul. 
toprak.), "Acal kelse altın taktan payda cok." (Ecel gelince altın tahtın faydası yoktur.), "Can bar cerde kaza (ce ölüm) bar." (Canın olduğu yerde ölüm var.) sözleriyle ecelin her şeye kadir olduğu, zamanın kifayetsiz kaldığı, kaçışın olmadığı ve eninde sonunda bedenin kara toprakla sarmaş dolaş olacağı fehmine varılırken halkın kaçınılmaz son olarak bilinen ölüm olayına yaklaşımı net olarak ortaya konmaktadır (İbragimov 2005: 19). Nihayetinde ölümle ilgili geleneksek inanış ve anlayış olgusunu bünyesinde barındıran Kırgız toplumunun, doğum gibi ölüm olayını da doğal bir durum olarak kanıksadığı ve benimsediği anlaşılmaktadır.

\section{Ölüm Olayının Toplumdaki Yeri}

İnsanoğlu hayatı kavramaya başladığı andan itibaren ölümün zamansız, bilinmez, korkulan bir son olduğunun farkına varmıştır. Bu kavramla ilgili pek çok tören, inanış, davranış biçimi oluşturmuştur (Seçkin 2016:233). Ölüm olayının tolumdaki yeri ile ilgili olarak Kırgız toplumu için ölüm hadisesi, hüznün ve acının ram olduğu bir andır. Bu itibarla halk nazarında ölüm ve "acal" (ecel) olgusuna ilişkin birtakım inanışların ortaya çıktığını görmek mümkündür. Dolayısıyla ölüm olayına yönelik olarak halk arasında dünyaya kazık çakan hiç kimsenin bulunmadığ1 (Düynögö türkük bolçu eç kim cok.), ölümün genç ihtiyar herkesin bir gün kapısını çalacağı söylenir. Dolayısıyla "ömür suusu tügönü̈̈" (ömür suyu tükenmiş) yani eceli gelen (acalı cetüü) herkesin bir gün musalla taşını göreceği, "calgan düynö" (yalan dünya) ile hesabı kesileceği ve vedalaşarak (koş aytışuu) göçüp gideceği şeklinde izah getirilir. Bu anlamda "Ölüm ak, ölümdön eç kaçan kutula albaysın, acalın cetkende ölösün, ömür calgan ölüm ak." (Ölüm hak, ölümden kaçış yok, ecel kapıyı çalınca öleceksin, ömür yalan ölüm hak) şeklindeki ifadelerle halk ölümün kaçınılmaz son olduğunu gerçek anlamda telakki etmiş durumdadır. Ayrıca ölüm ile ilgili olarak göz yumduktan ve dünyadan göçtükten sonra "Söögün söpöt bolot, canın uçup ketet." (Kemiklerin yok olup çürür, canın uçar gider.) denilir (Ünal 2010: 241). Böylelikle ölüm olayının vuku bulması halinde ten ve tın³ının ne olacağına dair düşünceler de alenen dile getirilir (Atalay 1992: 339).

Kırgız toplumunun acıklı ve kederli bir olay olan ölüm hadisesini açık olarak dile getirmekten sakındığı görülür. Nihayetinde bu durum çoğu zaman kinâyeli, mecâzi lafızlar eşliğinde ölüm veya öldü tabirini kullanmaksızın ifade edilir. Zira halkın doğrudan doğruya ölüm lafzını duyduğunda ürperti geçirdiği tespit edilir. Örtmece ifadelerde bu durum hafifletmeye gayret eder. Bu itibarla ölüm hadisesi kişilere "köz cumdu" (göz yumdu), "düynödön kayttı" (dünyadan geri döndü), "can berdi" (can verdi), "kelbes saparga attandı" (dönülmez sefere çıktı), "alıskı colgo attandı" (ırak yola atlandı), "canı çıktı" (canı çıktı), "canı uçtu" (canı uçtu) (Kulmambetov 2002: 39), "canın taslım kıldı" (canını teslim etti), "kaza taptı" (vefat etti), "kurman boldu" (hayatını kaybetti) gibi ifadelerin yanı sıra "kaza boldu", "üzüldü" (Tsirtautas 1976: 75 ) ve "kaytış boldu" şeklindeki tabirlerle de karşıdaki kimseye izah edilmeye çalışılır. Ayrıca ölen çocuk için "çarçadı" (yoruldu) veya "uçtu" (uçtu) tabiri kullanılmakla beraber uçtu tabirinden aynı zamanda büyüklerin ölümünü duyurmak içinde istifade edilir. $\mathrm{Bu}$ anlamda uçmak fiilinin törensel durumlarda ve istatiksel olarak diğer sözcüklerden daha fazla kullanıldığı anlaşılır. Kişinin öldükten sonra arbak yani ervaha dönüşen ruhun ulvi şahsiyetlerin "çımın" (sinek), çocukların ervahının ise kuş suretini aldığına inanılır (Bayaliyeva 1972: 62; Attokurov 1997: 141). Bu duruma ilişkin olarak eski Türklerde, kağan ve bey gibi asil kimselerin ölümü sonrasında ruhlarının kuş gibi göğe yani Tanrı'nın yanına uçtuğu inancı ile benzerlik gösterir (Tekin 2008: 29; Yüksekkaya 2009: 14-16; Erdem 2002: 167-175). Çok eski dönemlerden beri hemen hemen bütün Türk topluluklarında birinin kendi akrabalarının ya da saygı duyulan

3 Tın: ruh, nefes. "anın tını kesildi"= (onun soluğu kesildi, ruhu çıktı). Geniş bilgi için bk. (Atalay 1992: 339; Auezova, 2005: 504). 
kimselerin ölümünü belirtmek için "ölmek" fiilini kullanmaktan kaçındığ dikkat çeker. Orhun Yazıtlarında aile bireylerinden birinin ya da saygı değer bir kimsenin ölümü "uça bardı" (uçupgitti), "kergek boldu" (gerek oldu, yok oldu) gibi örtmece ifadelerle dile getirilmiştir (Tsirtautas 1976: 75). Batı Türklerinde İslâm'ın kabulünden sonra bile "öldü" yerine şonkar boldu yani "şahin oldu" sözü seçilmiştir. (Arık 2010: 12; Yüksekkaya 2009: 16-17)

Ölüm ve hayvan ilişkiselliği üzerinde yapılan pek çok simgesel biçim vardır. Hayvanlarla ilişkili ölümün simgeselliği, kimi zaman ruhun çeşitli hayvanların bedenine girerek dünya üzerinde gezmelerini ya da yaşamaya devam etmelerini ifade eder. Hayvanlarla ölüm ilişkisini ön plana çıkartan ilk unsur ruhun benzetildiği hayvandır (Sağır 2014: 174). Ölüm ile hayvan simge ilişkiselliğinde ruhun bedenden çıkışının kuş şeklinde tasviri sıklıkla karşımıza çıkan bir vakadır. Türk kültüründe ruhun kuş dışında başka bir canlı suretine bürünerek sık sık geri dönüşü söz konusu edilmektedir. Kuşkusuz bu geri dönüşler hayvan temsiliyle yapılmakta ve yaşayanlarla ölüm sonrası ruhların birlikteliğini yansımaktadır. Böylece ölen kişi aslında toplumsal bağlamından hiç kopmamaktadır (Sağır 2014: 176).

Ölüm hadisesinin gerçekleşmesi halinde hem ölen kişiye karşı acı ve hüznü bildirmek hem de cenaze sahiplerinin durumunu ifade edebilmek adına bazı tabirler kullanılır. Bu sözlerin hem yakınma hem de kaygı belirtiği görülür. Bu anlamda ölen kişinin genç olması halinde "caş ketti" (genç gitti), "içeer suusu uşul bele!” (içecek suyu bu kadar mıydı!), "kara tumandı baştarına salıp ketti" (kara dumanı başlarına bırakıp gitti), "katuu küydü" (çok yandı) "çögüp ketti” (göçtü, dalıp gitti), “öksüp ketti” (çöküp gitti, çöktü), “caş uluk emes acal uluk” (yaş değil, ecel büyük), "içeer suusu, köröör künü büttü" (içecek suyu, görecek günü bitti) şeklinde tabirlerin yanı sıra (Akmataliyev 2002: 107) "kalan caşın baldarına versin" (kalan yaşını çocuklarına versin) gibi ifadelerle arkada kalan insanlara uzun ömür temennisinde bulunulduğu (Ünal 2010: 223) gözlemlenir.

$\mathrm{Bu}$ anlamda örtmece üzüntü verici ya da ayıp sayılan kavramlarla ilgili tabular günlük hayatta bugün de önemli rol oynamakta ve bu anlamda sıkça örtmeceler kullanılmaktadır. İnanışlar bir toplumun örf, adet ve geleneklerini etkilediği gibi dilini de etkiler. Bu bağlamda korkulan, kaçınılan durumlar ya da varlıklar ile birçok durumda ahlakî değer ve nezaket kurallarına dayalı sakınmaların neticesi olarak ortaya çıan örtmece sözlerle inanışlar arasında doğrudan bir ilişki söz konusudur. Toplumun koyduğu yasakların ve ahlak kurallarının çerçevesinde oluşan ve kelimenin veya sözün anlam alanını değiştirmeyi amaçlayan örtmece, bir bakıma algılama olayıdır ve psikolojik bir boyut da taşır. "Örtmece, anlam değişmediği hâlde algılamayı değiştirmeye yönelik bir anlatım tarzıdır" (Demirci, 2009: 22).

Kırgız toplumu gökyüzü ile yeryüzü arasında meydana gelen dinsel ve büyüsel ilişkinin sonucu olarak insanların semada bir yıldızı olduğuna hükmeder. Bu anlamda cıldızı bar kişi ve cıldızduu adam ifadesini kullanırlar (Bayaliyeva 1972: 35). Ayrıca insanlar ve yıldızlar arasında sönme, kaybolma, göçme gibi unsurlarda benzerlik kurduğu görülür. Eski Kırgızların göğü Tanrı yani Teňir olarak algıladıkları, ay ve yıldız gibi gök cisimlerine ve bunların hareketlerine büyük ehemmiyet verdikleri anlaşılır (Murzakmatova 1997: 137). Bugün dahi halk arasında ölen kişiler için "cıldızı taydı" (yıldızı kaydı) tabirinin kullanılması bu durumun bir tezahürü olsa gerekir. Canın gökyüzünde (asman) bir yerde bulunması tanımı, diğer anlamda tının konumunu tayin etmesi bakımından önemlidir. Hemen hemen Türk halklarının geneli öbür dünyada ikinci bir hayatın varlığına ve ruhların ebediliğine inanır (Kafesoğlu 2002: 290-304). Özellikle İslamiyet'in kabulünden sonra tının veya ruhun rahat edebilmesini Kur'an'ın çok okunması ile ilişki kurulduğu gözlemlenir. Bu suretle ölen kişinin daima eş dostlarının yanında olacağına hükmedilir (Ünal 2010: 223). Eski geleneksel inanca göre ölüm sonrası ortaya çıkan 
"tozok" (cehennem), "beyiş" (cennet) anlayışının Teñirçilikte olmadı̆̆ gibi Teñirçilik inancında kişi ölmediği, sadece kişinin bedeni kocadıktan sonra Teñir'e atlandığı yani ona döndüğü şeklinde bir inanç yer aldığı da anlaşılır. Eski Kırgızların cesedi yaktıkları ve bu durumu "saparı karıgan soñ Teñire attandı." (sefer olgunlaştıktan sonra Tanrıya atlandı) şeklinde yorumladıkları görülür (Toktoşov 2005: 7). Günümüzde dahi kişi öldükten sonra bu dünyada nasıl biriyse narkı düynö olarak ifade edilen öbür dünyada da aynı şekilde terleyeceği inancı hâkimdir.

\section{Ölümün Habercisi Olan Belirtiler}

Yaşamın doğal sonucu olan ölüm, yok olmanın vermiş olduğu kaygı ve korkunun yanı sıra Kırgız toplumunda ve diğer Türk halklarında ata kültüne bağl1lıkları sebebiyle, bu olay yuğ törenlerinde ve defin ritüellerinde kısaca toplumsal yaşantıda derin izler bırakmasına neden olmuştur. Ölüm korkusunu bilinçaltına yerleştirmiş olan insan, üzerindeki bu baskıyı birtakım hadiselerle izah etmeye çalışır. Bu bağlamda ölüm olgusu olağan dışı davranışlarla, meteorolojik olaylarla, hayvanların birtakım hareket ve sesleriyle, uyku halinde görülen düşle ve hasta kişide meydana gelen fizyolojik-psikolojik değişiklikle izah edilmeye çalışılmış ve ölümün işareti olarak saymıştır.

Kırgız toplumunda ölümün habercisi olan ön belirti inanışının önemli bir yer tuttuğu gözlemlenir. Öyle ki hastada veya kişide vuku bulan bu fizyolojik ve psikolojik durum ile ilgili olarak uyku halinde meydana gelen düşteki vaziyet, üzerinde durulan hususların esasını teşkil etmektedir. Nitekim bazı kişilerin öleceğini rüyada gördüğü ileri sürülür ve bu durum halk arasında tüş bayan şeklinde ifade edilir. Genellikle rüyada ölen kişinin tanıdık birini çağırması halinde hanede birinin öleceğine inanılır. Bununla birlikte ölen bir kişinin rüyada evden bir şey götürmesi aynı şekilde evden birinin öleceğine delalet ettiğine kanaat getirilir. Yine rüyada bir yerden düşmek, suya düşmek, boynunun kesildiğini görmek, önceden ölen bir akrabası tarafından çağrılmak ya da ata bindirilip götürüldügünü görmek vb. bütün bunlar ölüme işaret sayilır (Polat 2005: 196).

\section{Vasiyet}

Kırgız toplumunda ölüm saatinin geldiğine hükmeden kimse ölmeden önce eşini dostunu bir araya getirerek son arzularını dile getirir. Bu istemlerin iletilmesinin iki şekilde meydana geldiği gözlemlenir. Bunlardan birini "kereez aytuu" (vasiyet etme), "kereez kaltıruu"nun (vasiyet bırakma) teşkil ettiği (Soltonbekov 2000: 69) ve iki sözden oluşan bu duruma ilişkin olarak kereez'in vasiyet, aytuu'nun söylemek fiilini oluşturduğu, kaltıruu'nun ise bırakmak fiilini ihtiva ettiği anlaşılır. Ölüm döşeğinde kişinin son sözlerini kapsayan bir diğer uygulamanın ise osuyat olarak bilinen nasihatin oluşturduğu görülür. Bu bağlamda ölüm döşeğinde yatan kişinin geride kalanlara karşı vasiyet ve nasihatını esirgemediği zikredilir. Ani ölüm olmadığı takdirde ölüm döşeğinde yatarken bir iki kelime olsa dahi kereez aytuunun icra edildiği söylenir. $\mathrm{Bu}$ anlamda vasiyetini bildirmeyen kişiye rastlamanın imkansız olduğu ifade edilir (Kebekova 2001: 45). Vasiyet, ölecek olan kimsenin yakınlarına söylediği son sözleri olarak kabul edilir. Dolayısıyla halk nezdinde eskiden beri ifa edilen bu geleneğin bugün dahi önemini muhafaza ettiği dikkati çeker.

Kırgız toplumunda vasiyetlerin çeşitlilik gösterdiği görülür. Nitekim "caman coldo baspa, cakşı coldo bol, Alla Taalaga işenip İslam dinine inanıp ak bolup Alla Taalanın aldına ak tilegi menen bar." (kötü yola sapma, hak yolda ol, Allahü Teala'ya ve İslamiyet'e inan, pak ol, Mevla'nın huzuruna tertemiz olarak çı.) şeklinde vasiyette bulunduğu gibi ölüm sonrası 
ritüellerin nasıl icra edilmesi gerektiği konusunda da vasiyette bulunduğu görülür. Genel anlamda ölecek olan kişinin vasiyeti, aile bireyleri arasında birlik ve beraberliğin devamlılığını, cenazenin kim tarafından yıkanacağı ve nereye gömüleceği yönündeki durumları muhteva ettiği anlaşılır. Osuyat'ın genel anlamda iyiliğe ve güzelliğe çağırma biçiminde şekillendiği gözlemlenir. Salt olarak yerleşen adetlerin eskiden beri kuşaktan kuşağa, ağızdan ağıza söylenerek oluştuğu bilinmekle birlikte (Ünal 2010: 224-226) osuyat'ın sinırlılık, kereez aytuu'nun ise geneli ihtiva eden bir durum sergilediği ifade edilebilir.

Herkes, kereez aytuu hakkına sahip olsa da genel olarak idareci zümre, itibar sahibi şahsiyetler, kahraman olarak addedilen şahıslar, yazar veya şair takımı kimselerin sözü "bayagının kereezi" (eskilerin vasiyeti) şeklinde halk arasında itibar görür ve dikkate alınır (Kebekova 2001: 43). Arkada kalanlara, yakınlara ve topluma kılavuzluk etmesi açısından büyük ehemmiyet taşıyan bu durum önemli bir yere sahiptir. Nitekim vasiyet bırakan kişi kendinden sonraki nesle yeni bir umut kaynağı sunduğu ve ona bir hayat iksiri bağışladığı gözlemlenir. Hayatta kalanın yaşamını devam ettirmesi için bir gerekçe hazırlar. Böylece insan yaşantısı bu bitmez tükenmez uğraşlarla ara vermeksizin sürüp gider (Iysayeva 2003: 76-80).

Kırgız toplumunda kereez aytuu ritüeline hemen hemen her dönemde rastlamak mümkündür. Nitekim Kırgız ilinde sömürgeci idarenin yerleştiği sıralarda halkın ağır bir baskıya maruz kaldığı süreçte horlanmaya ve özgürlüğünün elden gitmesine razı olmayan bazı kimselerin bu gidişata kayıtsız kalmadığı görülür. Çarlık idaresine boyun eğmeyen fakat kendi öz kardeşlerinin ihanetine maruz kalarak bir süre sonra ele geçirilen, Alma Atı'da bir hapishaneye atılan ve şüpheli bir şekilde hayatını kaybeden Balbay bunlardan sadece birisidir. $\mathrm{Bu}$ kişinin vasiyeti üzerine ölümünü takiben kemiklerinin etten sıyrılarak keçi tulumuna konulmuş bir şekilde getirilerek Isık Göl'deki Sarı Bulak köyüne (bugünkü Balbay köyü) gömüldüğ ü ifade edilir (Kebekova 2001: 46).

Kereez kaltıruu'ya ilişkin olarak ölüm döşeğinde olan Ormon Han'ın da Bugu boyunun önde gelenlerine dönerek son ricası olan vasiyetinde: Cesetimi (söök) temizce yıkatıp ak kefen ile kefenleyip, ak keçeye sarıp, ak deveye yükleyin. Kızım Kulan, ak boz dişi bir ata binerek aklar giyip devemi sürsün. Benim doğup büyüdü̈̆̈̈m Celargı Taylak'a götürülmem için izin verin. Benim naaşım oraya gömülsün der ve akabinde kızı Kulan'a dönerek kızım ben yıldızlar doğduğunda öleceğim. Naaşımı ilime ulaştır. Kırkım doluncaya kadar başımda ol. Kırk aş olduktan sonra Bugulara giderek orada yaşa. Babamı öldürdü diye Bugu'nun bir kişisini dahi hor ve kötü görme. Senin elin yurdun Bugular. Önceden nasıl davraniyorsan bundan sonra da öyle hareket et. Bugular ile el olarak kal şeklindeki vasiyeti halk arasında hala tazeliğini muhafaza etmektedir (Soltonbekov 2000: 69)

Manas destanında da bahsi geçen konuya ilişkin olarak malumatlara ulaşmak mümkündür. Nitekim Manas hastalığı ağırlaştığı bir zamanda eşi Kanıkey'i yanına çağırarak:

Elini ver de vasiyetime kulak sal. Akıllı cansın, yıkılmadan ayakta sağlam dur. Aklına iyice sok. Ecel gelip saat vakit dolduğunda ocağın sönmüşçesine davranma. Görmeden yürüyüp dalıp gitme. Başına ağ takılmasın. Han tahtı kanlı kesinlikle hazır ol. Semetey on iki yaşa gelinceye dek destek edin Bakay'ı. Tahtını elden çıkarma. Semetey on iki yaşına girdiğinde kılıcın keskin ucundan atlatıp, ak keçe giydirip oturt tahta. Eğer onu yapmaya kuvvet ve takatin yoksa eri ölen hatuna kendi hısımları daha yakın olur. Semetey'i kucakladığın gibi baban Temirkana kaçıp sığın. Abıke ile Köböş iki haram kişi kötülük eder ki ailene sığınmış olsan dahi. Semeyet on ikiye basınca ok geçmeyen keçe giydirip, Talas yerinden ve efradından bahset. Canını yaktığım Hanlar var hor görülen canlar var öçlerini almak isteyip mezarım açmasın, yol üstünde sürüyüp, naaşım pare pare kılmasınlar. Gözü karam bu işe dikkat kesil. Bakay'a nasihat et, hiçbir kişiye belli etmeden, hiçbir kişiye dahi 
göstermeden, sağlam kafayla düşün naaşımı bir canın dahi bilmediği yere gizle biçiminde vasiyette bulunmuştur (Iysayeva 2003: 77)

Kökötöy Han ise "Menin közüm cumulganda söögümdü kılıç menen kırdırtıp kımız menen cudurtun, çarayna menen çaptatıp (bulgaarı) menen kaptatıp anan Kıbılaga baştatıp koygula" (Gözlerim yumulduğu zaman cesedimden kemikleri kılıç ile sıyırın ve kımız ile yıkatın. Zırhı giydirerek "bulgaarı" (telatin) ile kapladıktan sonra başımı kıbleye doğru çeorik koyun şeklinde vasiyet ettiği anlaşllır (Cumagulov 1995: 11). Yine bu anlamda Solto urugunun önde gelen şahsiyetlerinden biri olan Özübek Bay ölmeden önce, bana aş verip at yarışı yapacağız diye zahmete girmeyin. Ben hayatımı zevk sefa içinde yaşadım. Ona binlerce tövbeler olsun. Aş yerine mezarıma kümbet yapınız diye halkına vasiyette bulunur (Kasırov 1999: 6). Er Töştük Destanında da vasiyete ilişkin saflara rastlamak mümkündür (Akmataliyev 1996: 115-119).

Kırgız toplumu ölen kişinin kesinlikle vasiyetinin yerine getirilmesi gerektiğine inanır. Bu işi boynuna alan kişi tarafından öncelikle takibi gerekmektedir (Abdılda Uulu 1999: 6). Zira kereez, ölen kişiden kalmış son hatıra veya anı sayılır (Murzakmatova 1997: 175). Bu anlamda merhumun ölüm öncesi söylemiş olduğu vasiyetini yerine getirmek ölen kişiye olan son vefa borcudur ve vasiyetin icra edilmesi kutsal bir görev olarak addedilir (Iysayeva 2003: 78). Bu arada halk arasında ölen kimsenin vasiyetini yerine getirmek ölmüş kimsenin diriler üzerindeki en önemli haklarından biri olarak telakki edilir.

Kırgız toplumunda vasiyetin icrası söz konusu olmakla birlikte bazı vasiyetlerin yerine getirilmesinde bazı istisnaların olduğu tespit edilir. Narın bölgesinde babam ölüm döşeğinde benden kendisi öldü̆̆̈̈ zaman cesedinin bir kırın koyuna veya bir dağın başına bırakmamı vasiyet etmişti. Ben bu duruma razı olmayarak vasiyetini yerine getirmedim ve hatta onu İslâmî kaidelere göre defnettik. Bir ara mezarın yaptırmamayı dahi düşündüm. Fakat elin dilinden kurtulmak için "beyit başı" olarak bilinen mezarını dahi yaptırdım şeklindeki vasiyet anlayışının Kökötöy'in vasiyeti ile benzerlik gösterdiği görülmektedir (Ünal 2010: 218). Manas destanında Kökötöy'ın ağır bir hastalığa yakalanıp ölüm döşeğinde yatarken, Baymirza adındaki kardeşine "Cıygan malım altınkümüşüm beker cerinen çaçılbasın kazınamdın oozu açllbasın." (Yı̆̆mış olduğum malım, altıngümü̈şüm boş yere saçılmasın, hazinemin ağzı açılmasın.) şeklinde vasiyette bulunduğu görülür. Fakat Manas'ın başını çektiği ileri gelenler ve bilge şahsiyetler Kökötöy'ün kereez'ini kale almayarak Kökötöy'ün ölü yemeğini (aş) gelenek uyarınca eskisi gibi şatafatlı ve tantanalı olması yönünde karara varırlar (Askarov 1996: 169-171). Bu bağlamda süreç içinde kereez gibi önemli âdetlerin kimi zaman uygulanmasında veya icra edilmesinde, gelenek ve törelerin belirleyici etken olduğunu söylemek mümkündür.

Vasiyet ve nasihat vermeden sonra hem ölüm döşeğinde yatan kişi için hem de onun yakınları için önemli olan bir diğer uygulama helallik iste gelirr. Nitekim eceli geldiğine hükmeden kişi son sözlerini söylemek için yakınlarını bir araya getirdiği ve vasiyetini ilettikten sonra helalleşme faslına geçtiği anlaşılır. Bu bağlamda hasta olan kişiyi ziyarete gelen konuklar tarafından helallik isteme durumunun ırazıçıllk suroo şeklinde ifa edildiği görülür. Toplum nazarında bu durum razılık isteme ve helallik sorma şeklinde kullanılır. Ayrıca hasta olan kişiyi ziyarete gelen kişilerin ölüm döşeğinde yatan kimseden helallik alma ihtiyacı hissettiği tespit edilir. Bu kapsamda ırazıçılık aluu durumu razllık alma veya helallik alma şeklinde ifade edilir. Bu itibarla kişinin çocukları ve yakınları helallik sormak için "ketken künööm bolso keçir." (kusur ve hatam varsa affedin.) diyerek helallik alma teşebbüsünde bulunur (Akmataliyev 2000: 230). Hasta olan kişinin helalliğini alma durumu ise ırazıçılıgın bildirü̈̈ veya ırazıçılııın bilgizü̈̈ tabiriyle ifade edilir ve karşıdaki kişiye hakkını helal ettiği anlamına gelir. Bu anlamda ölüm döşeğinde yatan kişi tarafından "Men silerge ırazımın, ölsöm söögüm ırazı, armansız caşadım, silerdin aldıñarga keteyin, ak kepindep, aruu cuup kömp kogula" (Ben sizlerden razıyım, ölsen naaşım 
razı, kaygısız yaşadım, sizlerin huzurunuzdan gideyim, ak kefene sarıp temizce yıkayıp defnedin.) şeklinde helalliğin iletilmesi vasiyetin tekrarıyla gerçekleşmiş olur. Çocukların annesinden ise "apa ırazılıgını ber, ak sütünön keç" (ana razı ol, ak sütünü helal et) şeklinde helallik istediği buna mukabil annenin "ırazımın, ak sütümdön keçtim" (sütüm helal olsun, senden razıyım) dediği ve helalleşme faslının bu veya buna benzer şekilde gerçekleştiği görülür. Bu bağlamda helalleşme durumunun kişilerin arsındaki muhabbete ve konuma göre farklılık gösterdiği gözlemlenir. Nihayetinde helalleşme faslı, Kırgız toplumunun anlayış ve inanışları çerçevesinde üzerinde hassasiyet gösterdiği ve dikkat ettiği uygulamalar arasında bulunmaktadır.

Sonuç itibariyle ölüm döşeğinde yatan kişi, son anlarını yaşadığı zannına kapılarak gerekli olan öğüt alacak, verecek hususları bildirmek amacıyla arkada kalan ailesini veya inançlı kişileri çağırır. Durumu ihtiva eden hususlar üzerinde gerekli olan vasiyetini iletir. Arkada kalan kimseler de ölen kişinin vasiyetini icra etmeye büyük çaba gösterir. Bu itibarla kereez'in ihtivası ölecek olan kişinin ailesi ve ölümünden sonra yapılmasını talep ettiği uygulamalardan oluşur. Aynı zamanda uruğ veya boyu ilgilendiren tavsiye ve nasihat de kereezi ihtiva eder. Bu yüzden bazı kişilerin kereezi boyun bütününün icra edeceği bir hüviyet kazanmış olabilir (Murzakmatova 1997: 170). Ölüm döşeğinde yatmakta olan kişi şuurunu yitirmeden evvel aile efradı veya yakınları "Söyleyeceğiniz bir şey var mı?" diyerek kişiyi ziyaret eder. Ziyaret ve çağrılma esasını ahirete intikal edecek olan ile arkada kalacakların koş aytışuu olarak ifade edilen vedalaşma durumu teşkil eder. Son demlerini aldığını hisseden kişi, çocuklarının abi ve kardeşlerinin kendisini öbür dünya (tigi döynö) ele güne karşı mahçup etmeden yolcu etmelerini temenni eder. Bu bağlamda hayatta arzu edip de muvaffak olamadığı işleri aile ve evlatlarına emanet eder. Evde kendisinin himayesinde olan öksüz, yetim kimse varsa veya özürlü kimse varsa ona herkesin iyi bakmasını, onu üzmemesini söyler. Merhumun son nefesinde söyledikleri kale alınır ve manidar bulunur. Ölüm döşeğinde yatmakta olan kişinin söylemiş olduğunun icra edilmesi ıyık parz yani kutsal vazife olarak telakki edilir. Kırgız toplumunda şifahen vasiyet etme işi gerçekleştiği gibi bazı zamanlar vasiyetin mezar taşına yazıldığı ve yazdırıldığı görülür.

\section{Ölüm}

Kırgız toplumunda kişinin öleceği anlışıldığında birtakım uygulamalara başvurulur. Bunun başında ölüm döşeğinde yatan hastanın yanına varsa molla çağrıldığı (Talıp Moldo 1993: 506566) veya oranın ileri gelen olarak bilinen aksakalının yanında bulunması sağlanır. Bu kişilerden biri henüz gelmemişse çocuklarından veya yakınlarından biri eceli gelen kişiye yardımcı olmaya ve kelime-i şehadet veya kelime-i tevhit getirmesine yardımcı olur. Bu kişilerin vefat etmek üzere olan şahsa kelime-i şehadet veya kelime-i tevhit getirtme işi halk nazarında ıyman ayttıruu şeklinde ifade edilir. Ölecek olan kişinin hasta yatağında bu kişilere eşlik ederek kelime-i şehadet veya kelime-i tevhid getirme durumu ise ıyman keltirüü veya ıyman aytuu şeklinde izah edilir. Esasında hem "1yman aytuu" (iman etme= iman söyleme) hem de "1yman keltirüü" (iman getirme) kelime-i şehadet ve kelime-i tevhit getirme ve söyleme ile aynı anlamı ihtiva eder. Bu anlamda kişinin üzülü̈̈ olarak ifade edilen canının bedenden ayrılma işi gerçekleşmeden önce ıyman ayttıruu ve ıyman keltirüü olarak bilinen şehadet işinin genellikle moldo olarak ifade edilen mollalarca ifa edildiği görülür (Talıp Moldo 1991: 61-63). Bu bağlamda eceli geldiğine inanılan kişi için "Aşhadu anlaa ilaha illallohu vo aşhalu anna Muhammeddin abluhu vo rasulluhu" diyerek sürekli olarak şehadet getirilir ve Amentü suresi tekrarlanır (Karasayev 1995: 484). Nihayetinde ahirete intikal edecek olan kişiyi İslami kaideye göre ve dini esas çerçevesinde ıyman aytuu işlemi ifa edilmektedir. 
Kişinin canını teslim etmesi çeşitli şekillerde izah edilir. Bu inanış çerçevesinde can algıç, azireyil ve can aluuçu perişte olarak bilinen Azrail'in insanın canını farklı şekillerde aldığına inanılır. Halk arasında insanın canını alan Azrail'in soğuk karşılandığı, kişinin canını iyi kişi veya kötü kişi olarak değerlendirdiği ve kişinin canını ona göre aldığına inanılır. Bu anlamda iyi kişinin canının kolay ve tez çıktığı, kötü kişinin ölümünün ise ağır ve zor olduğuna hükmedilir. Bu bakımdan "Ömürü camandın ölümü caman." (Ömrü kötü olanın ölümü de kötü olur.) anlayışı yer alır. Ayrıca Azrail'in insanın canını ağzından aldığına inanılır. Nitekim halk ölümden hiç bir zaman kurtuluşun olmadığına kanaat getirir. Sonunda "Ölüm acalın cetkende azreil canıbızdı Allanın buyrugu menen alıp ketet." (Ecel yetince Azrail canımızı Allah'ın emriyle alır.) diyerek ölüme teslimiyet gösterilir (Ünal 2010: 224-225).

Hastanın durumu ağır olduğu anlaşılınca akraba, komşu ve tanıdığı herkes hakkını helal ettirmek için akın akın ziyarete gelirler. Erken saatlerde hasta evine ziyarete gelindiği ve çoğu zaman bu ziyaretin akşam üzeri gerçekleştiği görülür (Kasımbekov 1989: 7, 12). Ruhunu teslim eden kişinin canını tutmaya çabalayacağı ve zorluk çekeceği düşüncesiyle yanında yüksek sesle bağrış çağrış edilmediği gibi ağlanmasına da müsaade edilmediği görülür. Ayrıca "Kıynoo tartpay ötsün." (Zorlanmadan acı çekmeden göçsün.) denilerek başının altındaki cazdık olarak bilinen yastık yavaşça alınır (Kasımbekov 1989: 7, 12). Ölümün kolaylaşması amacıyla molla veya yaşlı birisi tarafından kişinin ağzına su damlatılır. Genellikle ağza su damlatma işinin ölecek olan kişinin eşi tarafından yapıldığı anlaşılır. Ölürken kurumasın diye dudakları sık sık 1slatılır. Son nefesinde eğer varsa zemzem suyu verilir (Keskioğlu 1966-1969: 215-251).

Ölüm akabinde vücut soğuyuncaya kadar cesede dokunulmaz daha sonra yere boylu boyuna uzatılır (Talıp Moldo 1993: 537). Ölen kişinin eziyet göreceği düşüncesiyle elbisesi çoğu zaman kesilerek çıkarılır. Vefat eden kişi çene bırakması halinde avuç içiyle hafifçe çenesi itelenerek kımıldamaz bir şekilde tutulur. Can çıktıktan sonra mevtanın ağzının açık kalma ihtimaline karşı çenesi bağlanır (Kasımbekov 1989: 7, 12). İnanç anlamında kişinin ervahının yayılmaması, içine cin ve şeytan gibi mahlûkların girmemesi ve ağzı açık kalıp toprak dolmaması düşünülerek çenesinin bağlandığı görülür. Ayrıca bu anlamda gözü açık kalmasın denilerek el ucuyla ölen kişinin göz kapakları indirilir. Nitekim ölen kişinin gözünün kapatılmasında, dünyada gözü kalmasın, gözü açık kara toprağa girmesin ve ardından birilerini sürükleyip götürmesin anlayışı yatar. Bu bağlamda kapatılmış gözün tekrar kendiliğinden açılması halinde ölen kişinin amacına varamadan, ülküsünü kuramadan, muradına eremeden ve nihayete ulaşamadan ölüp gittiğine inanılır. Bu kişiler için halk arasında "köz açık ötüü”, “közü açık ketüü" (gözü açık gitti), "armanda ketüü” (gerçekleşmemiş arzu ve hayaliyle gitti) ifadesi kullanıldığı tespit edilir (Karasayev 1995: 245). Ölen kişinin ayakları ayrık durmasın düşüncesiyle birbirine bitiştirilir ve ölen kişinin yüzü beyaz örtü ile kapatılır. Akabinde su ile nemlendirilen kum, beze sarılarak ölen kişinin karın kısmına konur (Ünal 2010: 246). Cesedin serin ortamda muhafaza edilmesini sağlamak, şişmesini, kokmasını, içinin yarılmasını önlemek ve bastırmak düşüncesiyle ayrıca ölen kişinin karın kısmına taş, nemli toprak veya kum, "bede" (yonca), "çım” (çim, kesek çim) konur. Özellikle yazın sıcak aylarda ölen kişinin etrafına nemli toprak ve yonca serildiği ifade edilir.

Ölüm olayının vuku bulması sonucunda buna şahit olan kişi yerinden kalkarak "O o bir boorum bir boorumdan ayrıldım." (Oy biricik bağrım biricik kardeşimden ayrıldım.) şeklinde haykırır ve feryat eder (ökürüü). Bundan sonra çuu olarak ifade edilen gürültü ve feryatlar yükselir. İnsanların ağlamaktan ziyade feryat seslerinin yükseldiği görülür. Bu durum halk arasında "artında kalgandarı köp köz caşı töksö ölgön adam tigil döynödö köz caştan bütköp kölgö çögüp kıynalat" (arkada kalan kişiler çok gözyaşı döktüğü zaman ölen kişi öbür dünyada gözyaşından biten göle batar ve çok zorluk çekermiş) şeklindeki inançtan ileri gelse gerekir 
(Kasımbekov 1989: 7, 12). Bundan dolayı ölen kişiye duyulan acı ve yangın ağlayış şeklinde değil de genellikle haykırış şeklinde gösterildiği görülür. Nitekim çuu ve $\imath y$ biçiminde feryat nidaları duyulmaya başladığı andan itibaren kadınların çadırın içinde ağıt yaktığı erkeklerin ise bağrışarak ve haykırarak cenaze evine gelmeye başladığı gözlemlenir. Ölüm olayının vuku bulması akabinde kadınların koşok koşuu veya koşok olarak ifade edilen ağıt yakma, erkeklerin ise ökürü̈̈ olarak bilinen bağırış ve haykırış şeklinde acı ve kederlerini gösterdikleri tespit edilir. Akabinde ölen kişiyi uzatuu olarak bilinen yolcu edilmesi âdetlerine geçilir (Cusupbekov 1991: 39-40).

\section{Sonuç}

Günümüzde İslami kaideleri benimsemiş olan Kırgız toplumunda eski inanç manzumelerinin tesir ve canlılığından söz etmekle birlikte bu inançların bazıları zamanın akışı içinde anlayış ve uygulayış anlamında geleneksel milli bir yapıya bürünmüştür. Nitekim İslam öncesi ve İslam sonrası eski inanç ve inanışlar, halk arasında örf, adet, gelenek, görenekler şeklinde bazen İslamiyet ile bütünleşerek bazen de İslamiyet gibi algılanarak yaşayagelmiştir. Nihayetinde ölüm ve ölüm öncesi inanışların bu bütün içerisinde varlı̆̆ını devam ettirdiği görülmektedir. Ölüm ise kaçınılmaz bir son, yadsınamaz bir gerçektir. Her toplum da kendi hayatı algılama tarzı ve kültürü çerçevesinde örtmeceler üretmektedir. Normal şartlarda kötü olarak algılanan kelimelerin bir şekilde değiştirilip yeni ve farklı bir tarzda söylenmesi olarak bilinen örtmecenin Kırgız Türklerinde ölüm ile ilgili tüm ritüellere sirayet ettiği görülmektedir. Özellikle ölüm ile ilgili kavram ve inanışlar, insanın üzerinde oluşabilecek olumsuz etki algıyı azaltmak ve sıradanlaştırmak için etkin bir şekilde kullanmıştır. Özellikle bilinmeze doğru bir yolculuk olarak görülen ölümün yol açtığı korku, üzüntü de Türk halk inanış ve uygulamalarında örtmecelere, gerçeği gizlemelere ve saptırmalara önemli zemin hazırlamıştır. $\mathrm{Bu}$ dönemle ilgili korkular, endişeler, kaçınmalar, kaygılar, beklentiler ve nihai olarak inanışlar yalnızca örtmece sözlerde değil örtmece amaçlı uygulamalarda da kendisini göstermiştir. Bazı varlıkların zararından korunmak amacıyla başvurulan örtmece, saptırma ve gerçeği gizlemeye yönelik uygulamalar Kırgız Türklerinde örf, adet ve gelenekleri de şekillendirmiştir. 


\section{KAYNAKÇA}

ABDILDA UULU, Düyşan (1999. 07. 30), “Aza”, Kırgız Ruhu.

ABRAMZON, Saul (1999), Kırgıı cana Kırgızstan Tarıhı Boyunça Tandalma Emgekter, Bişkek: Soros Fondu.

AKMATALIYEV, Abdıldacan vd. (1996). Er Töştük, El Adabiyatı Seriyası, Bişkek: Şam.

AKMATALIYEV, Amantur (2000), Kırgızdın Köönörbös Döölöttörü, Bişkek: Şam.

AKMATALIYEV, Amantur (2002), Kaada-Salt, Ürp-Adat, Adamdik Oñ-Ters Sapat, Bişkek.

ARIK, Durmuş (2010). “Türk Halk İnanışlarında Örtmece ve Gerçeği Gizleme İle İlgili Uygulamalar: Doğum ve Ölüm Geleneği", Dini Araşttrmalar, Cilt: 13, Sayı:36, ss. 1-20.

ARPACIK, Yusuf Ziya (2008), Osman Batur ve Asrm İbretli Olayları, İstanbul: İlteriş Yayınları.

ASKAROV, T. (1996), "Kökötöydün Kereezi cana Obrazduu Oy Cürürtüünün Eski Katmarluu Strukturası", Manas Eposu cana Düynö Elderinin Epikalık Murası, Bişkek.

ATALAY, Besim (1992), Divanü Lûgat-it- Türk Tercümesi, 3. Baskı, c. I, Ankara: Türk Tarih Kurumu Basımevi.

ATTOKUROV, Sabır (1997), Kırgız Etnografiyası, Bişkek.

AUEZOVA, Zifa Alua (2005). Mahmud al Kaşgari Divan Lugat at Turk, Almatı: Dayk Press.

BAYALIYEVA, Toktobübü (1972). Doislamskiye Verovaniya i İh Perejitki u Kirgizov, Frunze: İlim.

CUMAGULOV, Acike (1995.12.01), “Tulparım menen Koşo Kömgülö”, Zaman Kirgızstan.

CUMAGULOV, Acike (1995.12.08), “Tulparım menen Koşo Kömgülö”, Zaman Kirgizstan.

CUSUPBEKOV, A. (1991), “Ata Dep Aytuu Kanday Sonun”, Kirgiz Ayıll, No:1.

CUSUPOV, Keñeş (2001), Bayırkının İzderi, Bişkek.

DEMIRCİ, Kerim (2008). “Örtmece (Euphemısm) Kavramı Üzerine”, Millî Folklor, Yı1 20, Sayı 77, ss. 21-34.

ERDEM, Mustafa (2002), “Kırgızlar'da Dini ve Sosyal Hayat", Türkler Ansiklopedisi, c. III, Ankara: Yeni Türkiye Yayınları.

GÖÇGÜN, Önder (1995). Dünden Bugüne Yunus Emre, Ankara: Atatürk Kültür Dil ve Tarih Yüksek Kurumu Atatürk Kültür Merkezi Yayını 92.

GÖKBEL, Ahmet (1998), Anadolu Varsaklarında İnanç ve Adetler, Ankara: Atatürk Kültür Merkezi Yayınları 158.

IYSAYEVA, N. (2003), “A. Cakıpbekovdun Teñir Manas Romanındagı Kereez Probleması", El Agartuu, 7-8: 76-80.

İBRAGIMOV, Muhamed (2005), Kırgız Makal-Lakap Uçkun Sözdörü, Karabalta.

KAFESOĞLU, İbrahim (2002), “Eski Türk Dini”, Türkler Ansiklopedisi, c. III, Ankara: Yeni Türkiye Yayınları.

KALAFAT, Yaşar (1990), Doğu Anadolu'da Eski Türk İnançlarının İzleri, Ankara: Türk Kültürünü Araştırma Enstitüsü Yayınları 112.

KARABULUT, Ferhat; OSPANOVA, Gulmira (2013). “Örtmece Sözlerin Mantığı: Kazak Türkçesi İle Türkiye Türkçesinde Karşılaştırmalı Model Analizi", Uluslararası Türkçe Edebiyat Kültür Eğitim Dergisi Sayı: 2/2, ss. 122-146.

KARASAYEV, Husein (1995), Nakll Sözdör, Bişkek: Şam.

KASIMBEKOV, T. (1999.03.02), “Ömür”, Kirgizstan Madaniyatı.

KASIROV, Mergenbay (1999.07.09), "Salttı da Şarttı da Karaylıçı", Zaman Kırgızstan.

KEBEKOVA, Batma (2001), Kırgiz Elinin Kaada-Salt Irları, Bişkek.

KESKIOĞLU, Osman (1966-1969), "Bulgaristan Türkleri Kocabakan Köyleri Folkloru”, Türk Kültürü Araştırmaları III-IV-V-VI, Ankara: Türk Kültürü Araştırma Enstitüsü.

KULMAMBETOV, Ö. (2002), Narın Kırgızlarında Doğum ve Ölü Gömme Adetleri, Bişkek: Kırgızistan-Türkiye Manas Üniversitesi Fen-Edebiyat Fakültesi Tarih Bölümü: (Yayınlanmamış Bitirme Tezi).

MAMBETKAZI, Eminalı (2004), "Irım-Cırım, Kaada-Salttardan”, Kırgızdar, Tom 4, Bişkek.

MOLDO, Talıp (1991), “Dindik Adattar”, Ala Too, No: 1.

MOLDO, Talıp (1993), Kırgız Tarıhı (Ed. K. Cusupov), Kırgızdar, Sancıra, Tarıh, Muras, Salt., Tom II, Bişkek.

MURZAKMATOVA, Aygul (1997), Kirgiz Etnografiyası, Narın. 
POLAT, Kemal (2005). Beşikten Mezara Kırgız Türklerinde Gelenek ve İnanışlar, Ankara: Türkiye Diyanet Vakfı Yayınları.

SAĞIR, Adem (2014). Ölüm Sosyolojisi, Ankara: Phoenix Yayınevi.

SEÇKİN, Kuban (2016). "Şecere-İ Terakime'de Ölüm Örtmecesi”, Karadeniz Araştırmaları, Yaz, Sayı 50 ss. 231-240.

SOLTONBEKOV, Berlik (2000), Kılımdardı Karıtkan Kırgızdardın Kaada-Salttarı, Bişkek.

TEKIN, Talat (2008). Orhon Yazıtları, Ankara: Türk Dil Kurumu Yayınları 540.

TOKTOŞOV, Kapar (2005.04.05), “Teñir cana Kırgız”, Aalam, No: 26.

Tsirtautas Laude, İlze (1976). “K Voprosu o Tabu i Evfemizmah v Kazahskom Kirgizskom i Uzbekskom Yazıkah", Sovetskaya Turkologiya, Akademiya Nauk Azerbaydjanskoy SSR, İyulAvgust No 4, ss.72-86.

ÜNAL, Ali (2010), Günümüz Kırgız Toplumunda Doğum-Ölüm Geleneği ve Bunun Tarihi İzleri (Narın Bölgesi Örneği), Bişkek: Kırgızistan Türkiye Manas Üniversitesi Sosyal Bilimler Enstitüsü: (Yayınlanmamış Yüksek Lisans Tezi).

YÜKSEKKAYA SAĞOL, Gülden (2009). Uçmă̆a Varmak Kitabı, “Türklerde Ölümün Algılanışı Ölmek Karşılığı Kullanılan Kelimelerden Hareketle”, İstanbul: Kitabevi Yayınları. 